\title{
A REVISION OF THE EUCALYPTS OF THE RYLSTONE DISTRICT.
}

\author{
By R. T. BAKER.
}

In a paper published in the Society's Proceedings for 1896 "On the Botany of Rylstone and the Goulburn River Districts," I recorded a list of Eucalypts collected by me up to that date. Since writing that paper I have several times visited the district and made botanical collections, so that my knowledge of the Eucalypts has considerably increased, and consequently I find that my previous views of these trees have somewhat altered, and in some cases I am not prepared to stand by my original determinations.

I wish now to modify some of my previous statements respecting certain species, to add new data regarding others, and also to re-arrange the species in a sequence founded on a classification which is not so restricted as that based on morphology alone.

The system now followed is that advanced by myself and colleague, Mr. H. G. Smith, in the work "Eucalypts and their Essential Oils." It is based on-

(1) A field knowledge of the trees,

(2) The nature and character of their barks,

(3) The nature and character of their timbers,

(4) Morphology of the fruits, leaves, buds, \&c.,

(5) Chemical properties and physical characters of the oil, dyes, kinos, \&c., and any other evidence, such as histology, physiology, \&c.

Such a classification, we think, is a nearer approach to a natural one than any of the other systems yet devised.

The range of several species is also considerably extended. 
I have to acknowledge my indebtedness to Mr. James Dawson, L.S., Surveyor for the District, where he has now been stationed over 25 years and whose knowledge of its Eucalypts is considerable, for kindly assisting me with many valuable field observations.

The geological formation of this district is very interesting, and I regret that I have not given more attention to the subject, as there appears to be a very close connection between particular species of Eucalypts and the soil. For instance, E. lcevopinea is only found on certain disintegrated igneous ground, and $E$. Dawsoni on a certain stratum below the sandstone of the Tomago Beds.

E. Trachyphloia, F.v.M. "Bloodwood."

No additional notes to those already given are available, as I have never found it in any but the one locality recorded.

E. Lævopinea, R. T. Baker. "Silvertop Stringybark."

This tree was first made known to science by me from material obtained on the Gulf Road and recorded under the name of $E$. obliqua in my first description of the Rylstone botany

I have since seen trees of the true E. obliqua in Tasmania, as well as in Victoria and this Colony, and am quite convinced that my previous determination was altogether wrong, through having laid too much stress on the shape of the leaves, for after describing the fruits as distinct from E. obliqua, I state " the shape of the leaves corresponds in every particular with all the descriptions and figures published of E. ooliqua." I doubt now whether it is ever found on the same geological formation as $E$. obliqua, for it occurs just below or on the summit of basaltic hills or mountains (J. Dawson). I think there can be no question now about its being a distinct species, for it possesses too many systematic and economic characters to be merged into any other. Nevertheless it should be mentioned that this view does not commend itself to some systematists (vide these Proceedings, 1896, p. 803 ; 1898 , pp. 28 and 798 ; 1901, p. 124 ; and also 
Maiden's 'Critical Revision of the Genus Eucalyptus,' where it is placed under five different species).

E. lcevopinea differs from-

(a) E. capitellata in the shape of its fruits, its timber, bark and oil constituents.

(b) E. macrorhyncha, in its fruits, timber, leaves, bark, oil constituents, leaf dye.

(c) E. pilularis, in its leaves, particularly in the dried state, buds, leaf venation, timber and oil constituents.

(d) E. Muelleriana, in timber, leaves, fruits, bark and dye of inner bark.

(e) E. dextropinea, in its timber (worthless), leaves, fruits, buds, and oil constituents.

E. Lactea, R. T. Baker. A "Spotted Gum."

Not previously recorded for this district. The "sucker" leaves readily distinguish it from $E$. viminalis, Labill., or E. maculosa, R. T. Baker. It is common on Mount Vincent, and some typical trees occur on the main Western Road, Blackheath, and main Southern Road in the Bargo Brush, as well as at O'Connell, near Brewongle.

It is therefore a tree with a fair range as far as at present known. The timber is of poor quality.

E. Conica, Deane \& Maiden. "Box."

In my original paper this was recorded as E. hemiphloia, F.v.M., from a casual field observation, but since receiving full material for oil investigation I am convinced that the tree is no other than that of Deane \& Maiden's species. Mr. Maiden, in these Proceedings, synonymises it with E. Fletcheri, R. T. Baker, which he also records as E. Baueriana, of Schauer, whose type specimens consists of leaves and buds only.

I fail to follow Mr. Maiden's line of argument in these Proceedings 1902 , p. 216 , concerning the phyto-chemical affinity of this species with that of $E$. ovalifolia, R. T. Baker; nor have 
these two species anything in common morphologically, and their timbers and bark are quite distinct.

E. Eugenioides, Sieb. " White Stringybark."

Fairly general throughout the district.

E. Rossir, R. T. Baker \& H. G. Smith. "Spotted Gum."

This tree I previously recorded under the name of $E$. homastoma var. micrantha. It has been found, however, that it possesses such distinctive characters from that species that it has already been given specific rank under the above name.

The timber is very hard, red-coloured and durable, and is far superior to that of E. hcemastoma, with which it has been synonymised by various authors working on dried material.

Camboon is the only locality I have collected it.

\section{E. Dealbata, A. Cunn. "Mountain Gum."}

This species, for some reason not clear to me now, I recorded under the name E. Gunni, Hook. f. It is well distributed in the district, and its occurrence so far east as Murrumbo is, I think, a record for this interior Eucalypt.

E. Maculosa, R. T. Baker. A "Spotted" or "Brittle Gum."

This species is common on dry, sandstone ridges of the western slopes of the Main Dividing Range, particularly at Mount Vincent, Ilford. The timber is poor and of little value even for firewood.

E. Camphora, R. T. Baker. "Sallow."

I am now convinced that my original determination, i.e., $E$. dealbata, was entirely wrong in regard to this Eucalypt, and that this species has little to connect it with that species.

I have since recorded it under the name of $E$. camphora from this as well as localities far removed from Rylstone. Deane \& Maiden express an opinion (these Proceedings, 1901, p. 137) that it is identical with E. ovata, Labill., concerning which species Bentham, who had access to all the European herbaria, states 
(B.Fl. iii. p. 200), “E. ovata, Labill., Pl. Nov. Holl. ii. 13, t. 153, from West Australia, does not occur in the distributed sets of Labillardière's plants which I have seen. From the figure, it appears probable that the specimen represented was from an adventitious branch, with much broader leaves than the ordinary flowering ones. It is very likely, therefore, a form of some one of the described Western species, possibly E. brachypoda." Labillardière gives a good plate of his E. ovata, collected near or on the coast at Cape Leeuwin, Western Australia, and it will no doubt yet be identified with a Eucalypt from that State.

This botanist could not possibly have collected E. camphora in his time, as its now known habitat was inaccessible in his day, and the species common to Eastern and Western Australia are all interior ones, whilst $E$. ovata, Labill., is coastal. Labillardière faithfully figures some particular species, but it certainly is not my E. camphora, which has quite different flowers, leaves and fruits.

E. punctata, DC. "Grey Gum."

I find now that two species were included under my original notes, viz., the true $E$. punctata occurring at Mount Vincent, and E. squamosa, Deane \& Maiden, under the name of "Ironwood" at Kelgoola. Grows under the sandstone cliffs (J. Dawson).

E. squamosa, Deane \& Maiden.

Some very tall trees of this species occur at Kelgoola under the name of "Ironwood."

E. Bridgesiana, R. T. Baker. "Woolly-butt."

Originally recorded by me as E. Stuartiana.

E. Goniocalyx, F.v.M. "Mountain Gum."

Not previously recorded, but it is a common tree in the Never Never country and Kelgoola. In the gullies radiating from Mt. Corricudgy it is very plentiful, and some enormous trees await the timber-getter. 
E. Globulus, Labill. "Blue Gum."

This species is common in the gullies of Never Never, via Kelgoola.

E. Cambagei, Deane \& Maiden. " Woolly-butt."

Occurs as far west as Hargraves. It has a "Box" bark and a timber (quite worthless) similar to trees of this species occurring in Victoria and other parts of New South Wales. It is a very constant species.

E. melliodora, A. Cunn. "Yellow Box."

This tree, like so many other Eucalypts, preserves in a marked degree its specific characters throughout the Rylstone District, where its representatives are identical with those found in Victoria and other parts of Australia.

\section{E. Dawsoni, R. T. Baker. "Slaty Gum."}

Found only on the eastern slopes of the Main Dividing Range in the watershed of the Goulburn River and always on the same geological formation, viz., the Tomago Beds. It is never confounded by settlers with the "Red Box," E.ovalifolia, nor is it to be expected when it is remembered that these people never confuse a smooth-barked (Gum) tree with a "Box"-barked tree. Its timber is excellent and quite equal to Ironbark (vide note below). It also occurs in Capertee Valley (J. Dawson).

E. ovalifolia, R. T. Baker. "Red Box."

A well distributed species in this State, but in this district is found on rather poor soil. As a rule the bark is smooth, but occasionally a rough bark occurs a few feet from the ground.

It is never so tall as "Slaty Gum," E. Dawsoni, and its timber is little sought after owing to its curly nature and pipy stem. The poorer the ridge the worse the timber (J. Dawson). I fail to follow Mr. Maiden's line of argument in these Proceedings, 1902 , p. 529, that there exists a phyto-chemical affinity between $E$. conica and this specimen, and the statement that I mixed the material sent to him is incorrect. 
E. ovalifolia, R. T. Baker, var. lanceolata, R. T. Baker \& H. G. Smith. " Red Box," "Slaty Gum."

This tree very probably owes its differentiation to environment, for I have only found it in rich, moist soil. It has a smooth bark, lanceolate leaves (broader than E. Dawsoni), and an excellent straight-grained, comparatively soft, red timber; in other respects it resembles the type. At Lue and along the banks of the streams that flow into the Cudgegong on its right bank from Rylstone to Gulgong, it is sometimes known as "Slaty Gum" (J. Dawson), but it is not the "Slaty Gum" of Bylong upon which $E$. Dawsoni was founded.

Remarks on the above three Eucalypts.

These were originally placed by me as varieties of $E$. polyanthema, Schauer, but during the last five years much in the way of new data has been collected concerning them, so that I have been led somewhat to alter my first classification, and I now regard them as quite distinct from that species and have so recorded them in these Proceedings.

E. polyanthema, Sch., has recently (Proc. Linn. Soc. N S.W. 1902, p 527) formed the subject of a paper by Mr. J. H. Maiden, who reproduces Schauer's original description from Walpers' 'Repertorium,' and also gives a figure drawn from the type specimen.

This description and figure refer to a tree that in no way can be made to include any of the above trees, although Mr. Maiden synonymises them with it (Schauer's E. polyanthemos). I have in my possession botanical material identical with those of Schauer's, in fact might be thought to be the type figured, and these are from a tree quite distinct from any of the above three. Schauer states of his tree, "Arborea glauco-virens; foll. coriaceis ovatis subito in petiolum contractis obtusis apiculatis, margine crasso subrevoluto cinctis impunctatis, utrinq. opacis."

Such features are not to be found in either E. Dawsoni, E. ovalifolia, or E. ovalifolia var. lanceolata, and one has only to know these trees in the field and to compare their herbarium 
specimens with the type figured by and in possession of $\mathrm{Mr}$. Maiden, to at once see how much the morphological differences are emphasised and therefore how absolutely distinct they are from Schauer's description and Cunningham's specimens. Although I am strongly opposed to laying much importance on fragmentary type specimens-in this case only leaves and buds are preserved, yet the slightest inspection will prove conclusively that these differ materially from the leaves and buds of the above three species.

The type delineated by Mr. Maiden exactly matches the "Grey Box" of Victoria-the "Red Box" of the southern interior and south-east corner of N.S.W., and the interior of N.S.W. west of the town of Bathurst, also the species figured by Mueller in his 'Eucalyptographia,' and whose description is that of a tree with a "Box" bark extending right out to the branchlets,-one point of distinction which is worthy of some attention in systematic work, but apparently has been entirely ignored, and which, I contend, should have been taken into account in this connection when synonymising. It is this tree that has been recognised as $E$. polyanthema in the work 'A Research on the Eucalypts.' It is a similar case to $E$. goniocalyx and $E$. elceophora, F.v.M., which species, till pointed out by me, were considered by some as one and the same tree, and as this latter species can be easily separated from Mueller's description of the former, so "Grey Box" of Victoria and the "Red Box" of N.S.W. with their persistent "Box" bark, can thus be separated from the smoothbarked Eucalypts recorded by Mr. Maiden under E. polyanthema. It is worthy of passing note that Mr. Maiden states :-

(1) "Tumut, H. Deane. Mr. Deane has the following note: 'Deciduous, smooth bark; var. E. polyanthema. Same as 'Red Box' from Queanbeyan apparently."

Evidently Mr. Deane was not prepared to place this tree with its smooth bark in the same specific rank as the tree with a "Box" bark, E. polyanthema, but gives it varietal position. I have seen these trees, and they are identical with the Rylstone Red Box, E. ovalifolia, and also show a constancy of bark over a large area. 
(2) "Red Box," Reedy Creek, near Gulgong, "narrow leaves," big trees, glaucous all over (J. S. Boorman).

The leaves illustrated by Mr. Maiden as Schauer's type are certainly not narrow, and this one feature alone is sufficient to indicate a change of species from that of the type, whilst these "big trees, glaucous all over" are certainly not E. polyanthema, Schauer, as such an expression could not apply to a "Box"-barked tree. I think these two instances alone will suffice to show to what extremes morphologists of the Muellerian school are prepared to go in uniting species.

Mr. Maiden further states, p. 528, "he found people indifferent as to the use of the names 'Slaty Gum ' or 'Red Box,' applying them indiscriminately as a very general rule." This is not the experience of myself nor that of Mr. Dawson, who is thoroughly acquainted with the whole Rylstone district.

The variety lanceolata is, in my opinion, a good definition of a variety. Its bark and oil are somewhat similar to the type, whilst it differs from it in the nature of its timber, and in the shape of its leaves and fruits.

The following table will prove conclusively the specific morphological differences of these Eucalypts, and although these are so well marked, the phyto-chemical ones are still more so.

1. E. polyanthema. - Leave s ovate, coriaceous, obtuse, apiculate, margins thick, subrevolute, venation distinct, intramarginal veins well removed from the edge, oil glands hidden. T i m b e $\mathrm{r}$ hard, close-grained, red-coloured. B a r k "Box" throughout. B u ds 2 to 3 lines in diameter, hemispherical to conical, contracted in the centre, pedicellate; operculum obtuse. Fruits conical, edge thin, notched, 2 to 3 lines in diameter. Oil constituents, eucalyptol, pinene, sesquiterpene, esters. Hab.-Victoria, N.S. Wales (Albury, Gerogery, Pambula, Bungendore, Delegate River, country west of Bathurst).

2. E. Dawsoni.-L e a ves lanceolate, glaucous, thin, intramarginal vein close to the edge, oil glands distinct. T i m be r deep red-coloured, hard, similar to Ironbark, straight in the grain. B a rk deciduous, slate-coloured or white, smooth. B u ds 
1 line in diameter, sessile or gradually tapering to the base, glaucous; operculum obtuse. Fruits small, 1 to $1 \frac{1}{2}$ lines in diameter, hemispherical or elongated, glaucous. Oil constit u ents, phellandrene, sesquiterpene. Hah. - Eastern watershed, Goulburn River Valley (Tomago Bedss).

3. E. ovalifolia.-L e a ves thin, ovate-lanceolate, venation distinct, intramarginal vein removed from edge, oil glands distinct. T i m b e r curly, red, hard, but not used as trees are always decayed in centre. Bark smooth or rough at the base for 2 or 3 feet. Fruits conical, pedicellate, rim thin, contracted at edge. Oil constituents, phellandrene, pinene, sesquiterpene. Hab.-Western watershed of Rylstone District, Tumut, Hargraves.

4. E. ovalifolia var.lanceolata.-L e a v e s thin, lanceolate, intramarginal vein close to edge, oil glands distinct. T i m be r excellent, red-coloured, durable, straight in the grain. B a r k deciduous, smooth, white. Fruits similar to 3, except not contracted at edge. Oil constituents, phellandrene, pinene, sesquiterpene. Hab.-Western watershed N.W. of Rylstone.

E. macrorhyncha, F.v.M. "Red Stringybark."

Through an error in my field notes, the remarks in regard to the quality of the timber given under this species refer to that of E.eugenioides. The timber of E. macrorhyncha is not considered good, and is only used when that of other "Stringybarks" is not available.

\section{E. Tereticornis, Sm.}

Previously the opinion was expressed that this Eucalypt "might be placed with $E$. viminalis," but I do not think so now.

The trees at the foot of the Nulla Mountain have a very long narrow operculum and correspondingly long narrow calyx.

The timber is considered good and durable.

It has an extensive range in the district.

$$
\text { E. albens, Miq. }
$$

As this tree is very distinct over a large area of country, I am still inclined to regard it as worthy of distinction from E. hemiphloia, 
F.v.M., as formerly stated. Also found in the Capertee Valley (J. Dawson) and Hargraves (R.T.B.).

E. viminalis, Labill.

The name "Brittle Gum" given amongst others to this species in the original Census has since been separated by me under the name of $E$. maculosa.

Occurs near most watercourses or low-lying land.

E. Capitellata, Sm. "Brown Stringybark.

I previously expressed an opinion that an apparent gradation exists between this species and E. eugenioides. These gradations I find upon further investigations are not so pronounced as originally appeared to be the case. The fruits show a variation, being sometimes hemispherical and slightly pedicellate and at other times sessile and with compressed sides.

\section{E. Hæmastoma, Sm. "Seribbly Gum."}

The trees at Coomber and Ilford have a large fruit with a red rim and thick coriaceous leaves, and so, closely match the Sydney trees which I regard as Smith's type.

E. sideroxylox, A. Cunn., var. Pallens, Benth. "Ironbark."

This species or variety has always appeared to me to present a difficulty in systematically placing, as its flowers and fruits are identical with those of $E$. sideroxylon-morphological characters that cannot be ignored by any systematist, and yet it possesses distinctive foliage, timber and bark. I am sometimes inclined to think it is the "Rotten Ironbark" mentioned by Cunningham in Field's 'New South Wales,' published in 1825, as that vernacular name fittingly describes the timber.

E. CRebra, F.v.M. "Narrow-leaved Ironbark."

A well distributed species in the district. Very plentiful at Murrumbo on the Goulburn River. 
E. siderophloia, Benth. "Ironbark."

I regret that no additional material has been obtained to assist in the further elucidation of the trees placed by me under this name, as the trees occur on ranges most difficult of access. The fruits and buds are sessile and far more angular than pertains to the Sydney form, and the operculum is also much more obtuse.

E. piperita, Sm. " "Peppermint."

Both varieties of this Eucalypt, i.e., those with the urn-shaped fruits and those with the pillular ones, are found to occur indiscriminately. Only one locality was originally given, but I have since found it at Cudgegong, Kelgoola, Rylstone, and Corricudgy Ranges.

E. amygdalina, Labill. " Peppermint."

Only one locality is given in the original paper, but it occurs also in most of the hills or ranges in the immediate neighbourhood of Rylstone.

E. Coriacea. "Cabbage Gum."

Not previously recorded, but common on sandstone ridges near Ilford.

E. Sieberiana, F.v.M. " Mountain Ash."

Not previously recorded. This species attains giant dimensions at Never Never and Kelgoola.

E. Dives, Schauer. "Peppermint."

Not previously recorded. Kelgoola to Mount Vincent and south to Wallerawang. It has much the same habit as those at Mittagong on the Southern line, and although some very large trees are to be found, the timber is considered worthless.

\section{E. stellulata, Sieb. "Lead Gum."}

This species occurs in the Capertee Valley as well as in the ranges west of it, as previously stated. This difference in altitude does not appear to produce any specific changes. 


\section{$2 \mathrm{BHL}$ Biodiversity Heritage Library}

Baker, Richard T. 1903. "A revision of the eucalypts of the Rylstone District." Proceedings of the Linnean Society of New South Wales 28, 349-360.

https://doi.org/10.5962/bhl.part.26354.

View This Item Online: $\underline{\text { https://www.biodiversitylibrary.org/item/30143 }}$

DOI: https://doi.org/10.5962/bhl.part.26354

Permalink: https://www.biodiversitylibrary.org/partpdf/26354

\section{Holding Institution}

MBLWHOI Library

Sponsored by

MBLWHOI Library

\section{Copyright \& Reuse}

Copyright Status: NOT_IN_COPYRIGHT

This document was created from content at the Biodiversity Heritage Library, the world's largest open access digital library for biodiversity literature and archives. Visit BHL at https://www.biodiversitylibrary.org. 